\title{
Formative research in teaching-learning of graduate students in higher education institutions - Case Peru
}

Yolanda Rodríguez de Guzmán ${ }^{1}$ Carla Cristina Tamayo Ly ${ }^{2}$

1. Escuela Profesional de Enfermería, Facultad de Ciencias de la Salud, Universidad Católica los Ángeles de Chimbote, Perú.

2. Escuela Profesional de Educación, Universidad Católica los Ángeles de Chimbote, Perú.
Among the missions and functions of higher education, article 1, the World Conference on Higher Education reaffirms the generation of knowledge through research and encourages learning; as well as provide appropriate technical skills to contribute to the cultural, social and economic development of societies and to the development of scientific and technological research, ${ }^{1}$ but in order for a person to have the capacity to produce permanent knowledge and learning, are required skills, abilities and attitudes for the research.

In the context of Latin America, specifically in Colombia, the National Accreditation Council ("NAC") started talking about formative research in the second half of the 1990s as the research which is done between students and teachers in the process of developing a program's curriculum and which is distinguishing of the dynamics of the relationship with knowledge that must exist in all academic processes, both in the students' learning and in the renewal of the pedagogical practice by the teachers. ${ }^{2}$

The formative research is defined as a tool of the teaching and learning process; and its purpose is to disseminate existing information and encourage the student to incorporate it as knowledge (learning). It can also be defined as teaching through research or teaching using the research method, ${ }^{3}$ constituting itself as a pedagogical strategy of character teaching for the development of the curriculum.

According to Elliot ${ }^{4}$ (cited by Cerda, 2007) for the development of classroom training research, there must be objective conditions in the educational institution, as a flexible, open and dynamic curriculum that accepts a diversity of skills, rhythms, cultural values, interests and demands which allow the articulation between the investigative and educational tasks and the development of the students.

Stenhouse ${ }^{5}$ proposes that the curriculum be the means by which the teacher can learn its art; can acquire knowledge and can test ideas and experience in practice, that allow one to improve the quality of teaching. In this sense, the curriculum is the tool that conditions the exercise of such experimentation in which the teacher becomes a researcher in the classroom of its own teaching experience; which has high power to influence in practice and to change obsolete educational models. This is due to the fact that it is built on teachers' real knowledge, since they address real concerns about complex hidden processes of classroom routine and because they constitute a natural process of evaluation as a research tool.

The Universidad Católica los Ángeles de Chimbote (ULADECH Catholic) promotes within its didactic model the development of activities of formative research, which is based on the Institutional Educational Project, which conceives the formative research as a cross-curricular axis, since the education is a process of socialization through which research is inherent in the life of the human being. It is expressed through the insertion of pedagogical activities related to the contents of the discipline, which promote the development of research capacities and the results of the research line in the curriculum learning plans of each subject, which cover the general areas of each study program.

The investigative monograph, tested by ULADECH Catholic and university professors as an institutional policy, is the technique that showed some effectiveness for the development of formative research, constituting a real research exercise and, in this sense, besides being a teaching strategy, also is an excellent mean of research training. The methodological rigor, when making use of the scientific method, and the thematic relevance are characteristic of the university monographs.

It should be added that it is essential that the formative research be conceived as a pedagogical strategy that allows the teachers to reflect on their pedagogical practices for a better quality of teaching; and students, to be architects of their own learning, developing research capacities, building knowledge or learning of knowledge, even if of existing 
knowledge. ${ }^{5}$ These strategies are aimed at the comprehensive appropriation of knowledge, its relevance is given by the curricular objectives; the research objective belongs to an established area of knowledge. The operation of the formative research in ULADECH Catholic is executed with practical methods of research teaching, such as seminar, case study; problem-based learning (PBL); portfolio; research projects, which align with their didactic purpose, in coherence with the object of study.

In conclusion, the formative research uses the investigation as a tool of the teaching-learning process, which objective is to disseminate the existing information and favor the student to incorporate it as knowledge. This type of research has the following objectives: to teach teachers and students to research; develop cognitive skills such as analytics, productive thinking, and problem solving; to familiarize students with the stages of research and the problems that arise; construct in teachers the culture of permanent evaluation of their practice.

\section{REFERENCES}

1. UNESCO. Conferencia Mundial sobre la Educación Superior Declaración Mundial sobre la Educación Superior en el Siglo XXI:Visión y Acción: 9 de octubre de 1998. [cited 2017 Oct 15]. Available from: http://www.unesco.org/education/educprog/wche/declaration_spa.htm

2. Restrepo Gómez B. Conceptos y aplicaciones de la investigación formativa y criterios para evaluar la investigación científica en sentido estricto. [cited 2017 Oct 15]. Available from: http://www.epn.edu. ec/wp-content/uploads/2017/03/Investigaci\%C3\%B3n-FormativaColombia.pdf

3. Parra Moreno C. Apuntes sobre la investigación formativa. Educ Educad [Internet]. 2004; [cited 2017 Oct 15]; 7:57-77. Available from: http://www. redalyc.org/html/834/83400707/

4. Cerda Gutiérrez H. La investigación formativa en el aula: La pedagogía como investigación. Bogotá: Editorial Magisterio; 2007.

5. Stenhouse L. Investigación y desarrollo del curriculum. 5ta. Ed. Madrid: Ediciones Morata S.L. 2003. [cited 2017 Oct 15] Available from https://books.google.com.br/books?id=TzGPp84l1 AC\&printsec=frontcover\&hl=pt-BR\&source $=g b s \_g e \_s u m m a r y \_r \& c a$ $\mathrm{d}=0 \# \mathrm{v}=$ onepage $\& \mathrm{q} \& \mathrm{f}=$ false 